\title{
NATO in Balkans and Crisis on BiH
}

\section{Blerina Muskaj}

PhD, University "Aleksandër Moisiu" Durrës-Albania

\section{Abstract}

The Balkan crisis is the result of a series of conflicts in various areas of political, economic and social life in the former Yugoslavia. Relations between the former republics show the complex character of European security. Without a sustainable development of the whole region, it is impossible to guarantee security throughout the European continent. Europe was shaken by the bloody events that marked the break-up of Yugoslavia. No one could have imagined that such violent military clashes could take place in a European country, 50 years after the end of World War II, and that hundreds of thousands of people would seek refuge throughout Europe. It was clear from the beginning of the crisis in Yugoslavia that the war would continue for many years and if the international community did not intervene the result would be many casualties. The United Nations, the European Union and the OSCE tried to prevent military conflicts between the nations of the former Yugoslavia, but they failed. National elites pursued a policy aimed at creating nation-states and had outside support from influential forces. To achieve this goal they were willing to pay any price. The collapse of the former Yugoslavia, in fact, meant the end of the process that had defined the development of Western Europe since the beginning of the 20th century, in the time between the two world wars. It was the beginning of nation-states. The Balkans had lagged behind in its transformation for many reasons and unlike Western and Central Europe, the Balkan states found themselves in a different wave of historical development, accompanied by conflict and chaos. The collapse of socialism had an impact on this situation, causing new economic and political conflicts. From this point of view, all the efforts of the European and international communities, aimed at controlling the situation after the breakup of Yugoslavia, had no chance of success.

Keywords: NATO, Ballkans, crisis, BiH

\section{Nationalism in the Balkans}

An assessment of the crisis in the Balkans based on the analysis of historical trends that marked the development of European countries in recent centuries does not exclude the question of what caused such a bloody dissolution of the former Yugoslav 
Federation. Nor does it rule out the question of the political and criminal responsibility of the leaders of the various national movements there, for crimes against humanity ${ }^{1}$.

Violent clashes in the region did not come only as a result of national prejudices and lack of democratic traditions; they were also caused by the incompetence and irresponsibility of political leaders, who could not achieve a division by peaceful means ${ }^{2}$. European countries have made every effort to condemn all forms of nationalism in the region. But it takes a long time to liberate the Balkans from nationalism. It is an influential power that has a strong impact on the political processes in all Balkan countries as well as in their interstate relations.

\section{NATO in the Balkans}

Since the end of the Cold War, NATO has become increasingly involved in peacekeeping and peacekeeping operations, sending its troops in support of the broader interests of the international community and working closely with other organizations to help resolve deep-rooted problems, to alleviate suffering and to create conditions in which peace processes can become independent. The first three NATO peacekeeping operations took place in Europe, Bosnia and Herzegovina, Kosovo and the former Yugoslav Republic of Macedonia, however the need for longterm peacekeeping is global. NATO foreign ministers acknowledged this at a meeting in Reykjavik, Iceland, in May 2002, stating that: "To carry out its full range of missions, NATO must be able to put into action bodies that can move rapidly, wherever necessary ${ }^{3}$. "They must carry out operations in remote areas and with great duration and achieve their objectives." This decision, in fact, paved the way for NATO to deploy troops, for the first time, outside the Euro-Atlantic area, to Afghanistan in 2003. Since then, the Alliance has also been involved in Iraq and Sudan's Darfur.

Thus, since the disintegration of the former Yugoslavia, the Alliance has paid a lot of attention and energy to the Balkans. Following UN ceasefire negotiations and peace deals in the conflict in Croatia, the Dayton Accords were the first in a long line of peace plans by which the international community sought to transform the chaotic and antagonistic Western Balkans region into an area. more cooperative and peaceful in the late 1990s and early 2000s4.

\section{The war is coming to Bosnia}

Unfortunately it is true that dialogue and cooperation are sometimes not enough to prevent the outbreak of a conflict. This was the case in the former Yugoslavia. Despite

\footnotetext{
1 Sims D. Anthony. 'Kombet dhe Nacionalizmi në erën globale', pg 23, Tiranë 2008.

2 Sims D. Anthony. 'Kombet dhe Nacionalizmi në erën globale', pg 23, Tiranë 2008.

3 Western Balkans Security Observer, 'How far is NATO from the Western Balkans? Debates in the Region', pg 10, Aprill-Juni 2007.

4 Western Balkans Security Observer, 'How far is NATO from the Western Balkans? Debates in the Region', pg 11, Aprill-Juni 2007.
} 
the fact that some countries were focused on the future and on building peace, in the early 1990s conflicts / hostilities, 'reckoning' and old 'frozen' anger from the Cold War emerged. In no other country were these demonstrated to be more present than in the Balkans. The slow disintegration of Yugoslavia over the past decade has highlighted the darkest elements of Europe's past: ethnic nationalism, irredentism, a sense of historical insult, and a willingness to use force to achieve their goals.

The truncated Yugoslavia was a state of Serbian nationality in all respects, which planned to build a "greater Serbia" from neighboring territories. With a developed and relatively balanced economy, both Slovenia and Croatia could confidently look forward to the prospect of independence. Having no large Serb and Croat minorities, Macedonia was able to declare independence and negotiate a peaceful withdrawal of the Yugoslav National Army, Yugoslavia, from its territory during the first months of 1992. Bosnia-Herzegovina did not have these advantages. Sarajevo faced unfavorable economic prospects, strong rivalries within the community, and the imminent threat of aggression from outside without much international support or true friends.

According to the 1991 census, Bosnia and Herzegovina's population consisted of 44 percent Muslims, 31 percent Serbs, 17 percent Croats, and 5 percent "others" (generally citizens who had chosen the Yugoslav name instead of belonging to a particular community. ethnic) ${ }^{1}$. Although there were compact areas of Serb and Croat settlements, most of the population lived mixed together. Although the percentage of the population mix was high, the communities retained a strong sense of identity. Bosnia-Herzegovina had a tradition of tolerance based on the komšiluk ideal (good neighborliness), but it was a tradition that further strengthened rather than weakened ties within communities. Bosnia's history is riddled with ethnic strife - the great Bosnian writer Ivo Andrić once referred to his country as "the land of hatred." Despite decades of peaceful coexistence under Tito, the bitter legacy of the war years remained alive. Ethnic mobilizations during 1990-91 rekindled fears in the country. The radical nationalist wing of the Croat-Bosnian faction did not hide its desire to join an independent Croatia.

The Bosnian Serb leadership refused to join what they perceived to be an aspiring Islamic state. Izetbegović and his supporters were unwilling to approve a partition of $\mathrm{BiH}$ that would leave them with a small, isolated territory that would not reflect their real superiority within the population. They aimed to maintain a united state that the Muslim community, with their growing demographic majority, could eventually have control. All parties were steadfast in their stance and prepared to fight to achieve their goals. The threat of violence was particularly high due to BiH's special place in Yugoslavia's military policy. About $50 \%$ of Tito 's UKJ was permanently located in BiH, and over $55 \%$ of Yugoslavia' s military industry and ammunition depots were located in the republic. It seemed clear that it would be impossible for Bosnia to sever its ties

\footnotetext{
1 Western Balkans Security Observer, 'How far is NATO from the Western Balkans? Debates in the Region', pg 11, Aprill-Juni 2007.
} 
with Yugoslavia without inciting violenc ${ }^{1}$. On March 26, 1990, Miloševi i's confidant Borisav Jović had already concluded that in the event of a secession "BosniaHerzegovina could not survive as a sovereign state, nor could attempts to control its territory unfold without blood loss. "As in the case of the Serbs in Croatia, albeit with lesser justification, the Serb community within $\mathrm{BiH}$ was an outspoken opponent of any partition project that would leave them a community within an independent state. On October 15, 19912, when SDA and HDZ representatives in the Bosnian parliament pushed for a "declaration of sovereignty" including the right to secede, Bosnian Serb leader Radovan Karadžić challenged lawmakers with the extraordinary statement that the declaration of independence represented "the road to hell". where "the Muslim nation could disappear with them."

During the political irregularities of 1990, Karadžić briefly supported the creation of a Bosniak Green Party, before moving to a more nationalist position and joining the ranks of the newly formed Serbian Democratic Party (SDS). Karadžić would become the leading force for the war in 1992, and consequently an unwavering supporter of Serb nationalist demands. In September, Karadžić's SDS sponsored the creation of four Serb autonomous provinces within Bosnia, and on October 26, it proclaimed the Serb National Assembly in Bosnia, chaired by Momčilo Krajišnik. A referendum on November 10th resulted in a widespread rejection of secession from Yugoslavia, and on December 21st, the Republika Srpska (Republika Srpska and Bosnia and Herzegovina) was proclaimed in order to maintain ties with Belgrade. The Croatian community followed the same path. Their HDZ party initially announced its support for a sovereign $\mathrm{BiH}$, but in November imitated the Serbs by creating two autonomous Croatian provinces.

Izetbegović claimed to represent the model of a multicultural Bosniak, but he worked to secure Muslim dominance in Bosniak institutions and supported the separatist aspirations of Sanjak's branching out of his movement within Serbia. The initiatives of both Serbs and Croats were declarations of war against the ideal of a united state.

On May 6, 1992, Karadžić met with Mate Boban, head of the HDZ, on February 1, 1992, in Graz, Austria, to discuss a division of BiH according to their mutual benefits ${ }^{3}$. The conspiracy between Serbs and Croats was to the detriment of the Muslim community. Karadzic coldly described BiH as "a state created by communists." Later in 1992, Boban argued for the removal of the Bosnian presidency on the grounds that "today Bosnia-Herzegovina has virtually ceased to exist as a state and when there is no state, a president is not needed." In the last week of February 1992, the US ended its silence,

\footnotetext{
1 Western Balkans Security Observer, 'How far is NATO from the Western Balkans? Debates in the Region', pg 11, Aprill-Juni 2007.

2 Western Balkans Security Observer, 'How far is NATO from the Western Balkans? Debates in the Region', pg 12, Aprill-Juni 2007.

3 Bashkurti L., 'Ballkani Diplomacia e Munguar', pg 102, Tiranë 2019.
} 
its reservation on the break-up of Yugoslavia, and chose to support the independence of the Bosniaks ${ }^{1}$.

In the aftermath of the war in Croatia, Washington faced strong internal pressure to oppose Serbian aggression, and key leaders were increasingly influenced by explanations that the main sources of the conflict held Belgrade accountable. Support for the division of the federation along the republic's borders led Washington to align itself with its European allies and seemed to provide a convenient premise for the overall management of the Yugoslav problem. Prompted by the US-led international community, Sarajevo held a referendum on February 29 - March 1, 1992. The Muslim and Croat communities voted overwhelmingly for independence - but the boycott of Bosnian Serbs was also almost unanimous. Based on this result and in a tense atmosphere with violent incidents and provocative rhetoric, the Bosnian government and their joint presidency, led by the leader of the Muslim faction, Izetbegović, declared independence on March 27th. In less than a week, it was followed by recognition of European countries and the US.

Fighting broke out immediately between Serb and Croat militants and law enforcement forces in Bosanksa Krajina, Posavina, and eastern Bosnia, and shortly after the declaration of independence on the outskirts of Sarajevo, fighting broke out between Serb militants and local police forces reinforced by Muslim militants. and criminal groups. On April 4, Izetbegović demanded the mobilization of all reservists and police forces in Sarajevo, following an SDS call for Serbs to leave the city. Two days later, Sarajevo was bombed by Serbian artillery stationed in the suburbs. In these first weeks, in a turbulent situation, the government's ability to maintain public order failed. On April 7, the Serbian People's Assembly, convened in Banja Luka, declared the independence of the Republika Srpska Republika Srpska on 13 August 1992, and Serb representatives Biljana Plavšić and Nikola Koljević resigned from the joint Bosnian presidency. The HDZ publicly supported the government in Sarajevo, and on April 7th, Zagreb granted diplomatic recognition to $\mathrm{BiH}$, but at the same time sought to strengthen Herceg-Bosnia autonomy in order to promote its possible union with Croatian dominoes. This goal was partially achieved on July 3, 1992, when Herceg-Bosna was declared an independent state with its own flag and armed forces². The disintegration of Bosnia-Herzegovina meant war. It was a war that in its early stages, the government in Sarajevo was not prepared to fight and that the international community that had encouraged partition lacked the will to get involved or curb it. On April 5-6, a week after nationwide demonstrations, tens of thousands of protesters gathered in front of the Bosnian parliament to demand new elections and a policy of reconciliation ${ }^{3}$.

\footnotetext{
${ }^{1}$ Bashkurti L., 'Ballkani Diplomacia e Munguar', pg 102, Tiranë 2019.

2 Bashkurti L., 'Ballkani Diplomacia e Munguar', pg 200, Tiranë 2019

3 Bashkurti L, 'Diplomacia vëllimi II', pg 98, Tiranë 2010.
} 


\section{Bosnia \& Herzegovina: It forces NATO to come out of its 'shell'}

Bosnia has been the "stage" of many things for the first time for NATO, and the decisions taken to respond to events in Bosnia have helped NATO adapt since the end of the Cold War and shaped it. this new evolution. BiH forced NATO to emerge from its 'Cold War shell', and forced the Alliance to adapt to the challenges of a much larger world. When the war first broke out in 1991 in BiH, NATO had never conducted operations outside its territory. He had never even considered taking on powerful peacekeeping operations. It had never had important relations with other institutions. The first important lesson BiH taught NATO was that it could not be left out of the rest of Europe. The change in this philosophy by NATO members was rooted in three main reasons:

First, the Alliance finally acknowledged that the weak measures taken were not enough to end the state of war. The Srebrenica tragedy, among many other horrors, made it abundantly clear that the UN simply did not have the military means to support and promote continued diplomatic efforts, and that only NATO could bring peace.

Second, NATO members finally agreed that massive human rights abuses in central Europe could not be tolerated and tolerated. Tolerating ethnic cleansing, concentration camps, and deportees would destroy long-term projects to build a new Europe based on shared values of peace and tolerance.

Third, NATO members realized that even conflicts outside the territory could undermine Euro-Atlantic security.

NATO first used force in BiH on February 28, 1994, when it shot down four Bosnian Serb planes violating a UN-imposed no-fly zone. NATO also launched its first air campaign, Operation Intentional Force, in August and September 1995. It helped end the Bosnian War and later facilitated a nine-year peacekeeping operation there, from December 1995 to December. 2004. NATO deploys its first peacekeeping force, IFOR, in December 1995.

The political basis for the Alliance's role in peacekeeping operations was laid at a meeting of NATO foreign ministers in Oslo in June 1992. At that meeting, the foreign ministers announced their readiness for peacekeeping activities under the auspices of the Security Conference and Cooperation in Europe (CSCE, later renamed the Organization for Security and Co-operation in Europe, or OSCE), on a case-by-case basis and in accordance with its own procedures. This included making Alliance tools and expertise available for peacekeeping operations. In December 1992, the Alliance announced that it was also ready to support peacekeeping operations, under the authority of the UN Security Council, because it is the one with the primary responsibility for international peace and security ${ }^{1}$. Considering peacekeeping and

${ }^{1}$ Hoti D., 'Premisat e misionit aktual të diplomaciesë Amerikane në Ballkan, pg 3, Tiranë 2019. 
sanctions, or embargo enforcement measures already taken by NATO countries, separately and as an Alliance, to support the implementation of UN Security Council resolutions related to the conflict in the former Yugoslavia, NATO foreign ministers testified that the Alliance was ready to respond concretely to further initiatives that the UN Secretary General could take to seek Alliance support in this area.

Between 1992 and 1995, the Alliance took a number of important decisions, leading to surveillance operations and, subsequently, to enforcing a UN embargo and UN sanctions on the Adriatic and the cessation of air traffic over BiH by the UN as a nofly zone ${ }^{1}$. The Alliance also provided close air support to the UN Defense Force (UNFPA) and authorized air strikes that would unblock the siege of Sarajevo and other threatened areas and were designated by the UN as safe areas.

On August 30, 1995, NATO aircraft carried out a series of precision strikes against selected targets in Serb-held positions in BiH. This marked the beginning of Operation Intended Force, NATO's seventh air campaign, which lasted until 15 September. The operation destroyed the Bosnian Serb liaison and, intertwined with a determined diplomatic effort, helped pave the way for a real ceasefire, moreover, it paved the way for successful peace talks in Dayton, Ohio, USA.

\section{Dayton Peace Accords}

Under the terms of the General Basic Peace Agreement in Bosnia and Herzegovina, commonly referred to as the Dayton Peace Agreement (MPD), signed in Paris on 14 December 1995, an Executive Force was established to oversee the implementation of the military aspects of the agreement ${ }^{2}$. (IFOR - Implementation Force) led by NATO, with 60,000 troops and a one-year stay. The force was deployed on 16 December, and the transfer of power from the UN Force Commander to the IFOR Commander took place four days later, bringing together all NATO and non-NATO forces. participating in the operation, under the command of IFOR ${ }^{3}$.

As of 19 January 1996, the parties to the MDP withdrew their troops from the separation area, on both sides of the accepted ceasefire line, and, from 3 February, all troops withdrew to the areas where they would be stationed under the terms of the agreement. The handover of $\mathrm{BiH}$ ethnic territories ended on March 19th, creating a new demilitarized zone.

At the end of June, the storage of heavy weapons and the demobilization of the required troops were carried out, in accordance with the MPD. After more than four years of conflict and the repeated failure of international initiatives to end it, in less than six months, the foundations were laid for the future peace and security of Bosnia and Herzegovina.

\footnotetext{
1 Bashkurti L., 'Ballkani Diplomacia e Munguar', pg 211, Tiranë 2019.

${ }^{2}$ Hoti D., 'Premisat e misionit aktual të diplomaciesë Amerikane në Ballkan, pg 3, Tiranë 2019.

3 Bashkurti L, 'Diplomacia vëllimi II', pg 98, Tiranë 2010.
} 
IFOR provided significant assistance in creating a secure and conducive environment for civil and political reconstruction. It also provided support for civilian duties, working closely with the Office of the High Representative (OLP), the International Operations Police Force (IFAC), the International Committee of the Red Cross (ICRC), and the Office of the UN High Commissioner for Refugees. (KLKBR), the International Criminal Tribunal for the former Yugoslavia (ICTY) and many other agencies, including over 400 non-governmental organizations active in the area. IFOR also assisted the Organization for Security and Co-operation in Europe (OSCE) in preparing for, conducting and observing the first free elections in September 1996 and, following these elections, supported the OLP in providing assistance to Bosnian entities. and Herzegovina in establishing new joint institutions. In addition, IFOR military engineers repaired and reopened roads and bridges and played a vital role in demining efforts, repairing railways, opening airports for civilian traffic, reactivating gas, water and electricity supplies, rebuilding schools and hospitals and the regulation of major telecommunications installations.

\section{Conclusions and recommendations}

The Balkans posed serious challenges to the factors committed to a more stable and peaceful Europe. Thus, the Balkans had a significant impact on NATO. The 1995 intervention in $\mathrm{BiH}$ was also the Alliance's first ground engagement and contributed greatly to the change and reshaping of NATO's identity in the post-Cold War period. Ever since it first intervened in the former Yugoslavia, it has changed and taken on a completely different role from the previous one, preparing for new challenges. Although NATO intervention in "outside territories" aroused considerable opposition within the Alliance, it had to cross the line of collective defense and develop its own crisis management capabilities. NATO's capacity and expertise to manage complex peace support operations have greatly increased over the last decade, especially in response to the wars since the break-up of the former Yugoslavia.

Attitudes towards operations across the Euro-Atlantic area have changed. While it took three and a half years of bloodshed in $\mathrm{BiH}$, and nearly a year of fighting in Kosovo before the Alliance intervened to end the fighting, in the case of the former Yugoslav Republic of Macedonia, the Alliance was engaged in 2001 at the request of Skopje. To prevent the escalation of the conflict that could degenerate towards a civil war. In fact, NATO is deploying troops in Afghanistan, in support of the broader interests of the international community, to help resolve deep-rooted problems, and to create the conditions under which various peace processes can take place. self-sustaining and unconditioned by external factors. NATO's role is irreplaceable in meeting the current global security challenges, which cannot be met by military instruments alone and moreover by a single country. NATO, with its presence in Southeast Europe, is expanding its European base and at the same time putting up a defensive wall against terrorist threats coming from the East, such as Al-Qaeda. 
Meanwhile, the issue of NATO involvement in the issue of energy security has recently become the subject of debate outside and inside the Alliance. With the recent crisis in Ukraine, the issue of energy was brought to the attention of NATO as well. Former Secretary-General Jaap de Hoop Scheffer has made it clear on the 60th anniversary of NATO that . According to these debates, some of the different areas where NATO should be involved are as follows: developing a common policy, military preparation and securing transit routes.

\section{Recommendation}

Thus, now is the time to complete the 'work' started in the Balkans - to give the final impetus to the full inclusion of this region in the European current before it has the opportunity to take steps backwards. It is recommended that the following steps be taken:

- The EU and NATO must reiterate their readiness to accept as members any country in the Balkans that meets the criteria for membership.

- NATO must make strong use of the means at its disposal to push for the necessary reforms - for example, the Membership Action Plan.

- In Bosnia, the West must continue to maintain a strong international presence and commitment until Bosnia implements reforms that seem far-fetched to be achieved.

- The West must continue its strong engagement in Kosovo - through the roughly 10,000 soldiers that make up the NATO-led Kosovo Force.

- Encouragement for resolving the name issue of Macedonia.

\section{Bibliography}

[1] Bashkurti L., 'Ballkani Diplomacia e Munguar', pg 200, Tiranë 2019

[2] Bashkurti L, 'Diplomacia vëllimi II', Tiranë 2010.

[3] Hoti D., 'Premisat e misionit aktual të diplomaciesë Amerikane në Ballkan, Tiranë 2019.

[4] Sims D. Anthony. 'Kombet dhe Nacionalizmi në erën globale', pg 23, Tiranë 2008. Western Balkans Security Observer, 'How far is NATO from the Western Balkans? Debates in the Region', Aprill-Juni 2007. 